\title{
Identifying Minerals of Environmental Concern in Soils from Smelter Operations Using Multiple Microanalytical Methods
}

\author{
H.A. Lowers ${ }^{1}$, D.J. Bove ${ }^{1}$, S.A. Morman ${ }^{2}$ \\ ${ }^{1}$ U.S. Geological Survey, MS973, Denver, Colorado 80225 USA \\ ${ }^{2}$ U.S. Geological Survey, MS964, Denver, Colorado 80225 USA
}

Historic smelters near Eureka, Nevada processed material from silver- and lead-rich ores from the1860's to 1891. Since that time, smelter effluent and mineralized rock in soils surrounding the smelter have weathered and reacted to create secondary minerals. Bulk chemistry (ICP-MS) of the soil samples and one-hour leach solutions of the same soils in simulated gastric fluid predicts $\mathrm{As}, \mathrm{Pb}$, and $\mathrm{Cd}$ to be $32 \%, 53 \%$, and $87 \%$ bioaccessible, respectively. X-ray diffraction of the soils did not detect phases that may be the source of these enriched elements. The purpose of this study was to locate, identify, and characterize the phases that contain the elements of concern.

Soil samples were mounted in epoxy and final polished with colloid silica. Samples were first examined with a field emission scanning electron microscope to identify grains and areas interest. High magnification secondary electron and backscattered electron images were acquired to document the size and surface of the phases as the mounted samples were placed in a gastric leach solution for one hour and imaged again (Fig. 1). Energy dispersive spectroscopy (EDS) was used for qualitative chemical analyses. Several phases could be identified, however, the energy resolution of the EDS left ambiguities as to the presence of $\mathrm{S}$ in phases with high $\mathrm{Pb}$ contents. Quantitative chemistry acquired with an electron microprobe (EPMA) and structural determinations by electron backscattered diffraction (EBSD) were used to confirm suspected phases (Fig. 2).

The primary ore grains identified include mimetite $\left(\mathrm{Pb}_{5}\left(\mathrm{AsO}_{4}\right)_{3} \mathrm{Cl}\right)$, arsenian pyrite $\left((\mathrm{Fe}, \mathrm{As}) \mathrm{S}_{2}\right)$, galena $(\mathrm{PbS})$, plumboferrite $\left(\mathrm{Pb}^{2} \mathrm{Fe}^{3+}{ }_{(11-\mathrm{x})} \mathrm{Mn}^{2+}{ }_{\mathrm{x}} \mathrm{O}_{19-2 \mathrm{x}}\right)$, carminite $\left(\mathrm{PbFe}^{3+}{ }_{2}\left(\mathrm{AsO}_{4}\right)_{2}(\mathrm{OH})_{2}\right)$, pyromorphite $\left(\mathrm{Pb}_{5}\left(\mathrm{PO}_{4}\right)_{3} \mathrm{Cl}\right)$, and beaverite $\left.\left(\mathrm{PbCu}^{2+}\left(\mathrm{Fe}^{3+}, \mathrm{Al}\right)_{2}\left(\mathrm{SO}_{4}\right)_{2}(\mathrm{OH})_{6}\right)\right)$. Products of the smelter processing include $\mathrm{Pb}-\mathrm{Zn}-\mathrm{Fe}-\mathrm{V}-\mathrm{S}$ rich condensate, metallic fragments, and glassy shards. Many of these phases are less than 20 micrometers in the long dimension. Particles in this size range, once airborne, can be inhaled or ingested. Phases of secondary origin include Fe-As oxyhydroxides and $\mathrm{Pb}-\mathrm{Mn}$ oxides with up to $5 \mathrm{wt} \%$ of $\mathrm{Sb}, \mathrm{Zn}$, and $\mathrm{Cu}$ which occur mainly as soil concretions and vug fillings. The majority of these phases are also less than 40 micrometers. Imaging of the phases before and after exposure to the gastric leach reveals the mimetite to be the most soluble (Fig. 1). For the most part, iron oxyhydroxide phases remained unchanged after the gastric leach. 

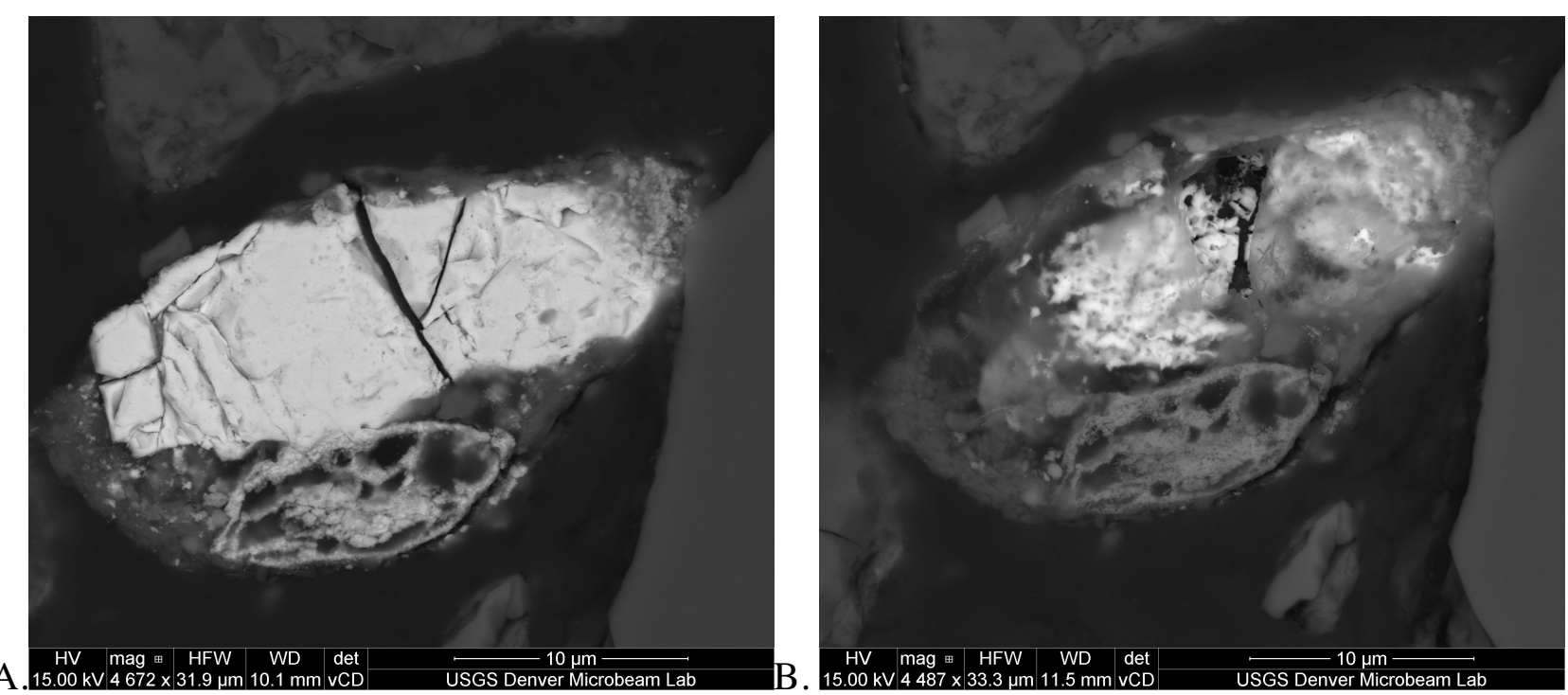

Fig.1. A. Backscattered electron image of mimetite $\left(\mathrm{Pb}_{5}\left(\mathrm{AsO}_{4}\right)_{3} \mathrm{Cl}\right)$ before simulated gastric leach. B. Same field of view as A after a simulated gastric fluid leach.

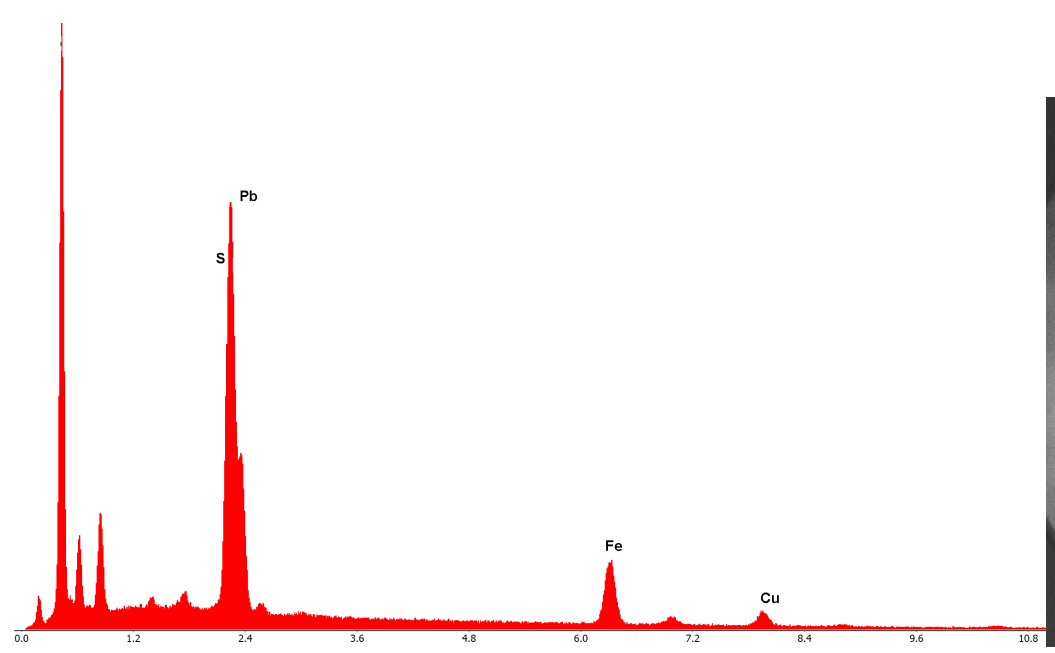

Fig.2. A. EDS spectra of beaverite. B. EBSD pattern of beaverite $\left(\mathrm{PbCu}^{2+}\left(\mathrm{Fe}^{3+}, \mathrm{Al}\right)_{2}\left(\mathrm{SO}_{4}\right)_{2}(\mathrm{OH})_{6}\right)$. 